\title{
The Life Esidimeni tragedy: Some ethical transgressions
}

Justice literally means equality and fairness - 'Justice as fairness. ${ }^{\text {'] }}$ In the milieu of healthcare and bioethics, justice is the process in which individuals are treated fairly and equally, resulting in the ability to achieve the highest attainable standard of physical, mental and social wellbeing. ${ }^{[2]}$ Justice is also the paramount obligation by states to ensure that all persons are treated fairly and equally in all sectors of society. ${ }^{[3]}$ As custodians of justice, the state has a legal and moral responsibility to ensure that it 'respects, protects, promotes and fulfils' the values of human life, 'dignity, equality and freedom. ${ }^{[4,5]}$

The Life Esidimeni tragedy occurred as a result of the rushed execution of the Gauteng Mental Health Marathon Project, when the Gauteng Department of Health $(\mathrm{GDoH})$ 'precipitously' terminated its contract with Life Esidimeni, a facility that provided 'highly-specialised chronic psychiatric care' to mentally ill patients ${ }^{[6]}$ Over 2000 mentally ill patients, some with comorbid conditions, were hurriedly moved to ill-equipped and unlicensed non-governmental organisations (NGOs) in an attempt to curb costs. An investigation by the Health Ombudsman found that these NGOs could not even provide basic healthcare to patients who required "highly-specialised chronic psychiatric care. ${ }^{\left[{ }^{[}\right]}$Additionally, the investigation found that in the process of moving patients and in the aftermath thereof, several human rights were violated - specifically the rights to health, life and dignity, resulting in a great injustice to society's most vulnerable group. ${ }^{[6]}$ The cruel and baseless decision by the Department to move patients resulted in over 140 (and counting) deaths. ${ }^{[7]}$

Justice also concerns 'democracy and the distribution of power, social roles, and capacity.[2] The application of justice in the healthcare sector by the state $(\mathrm{GDoH})$ 'ought to progress hand in hand toward a better ${ }^{[2]}$ society, but unfortunately, as was seen with the Life Esidimeni tragedy, this was not the case. Recipients of healthcare have specific rights with regard to its delivery, and these rights (life, health and dignity) are interlinked with principles of ethics (autonomy and informed consent, beneficence and non-maleficence) ${ }^{[8]}$ The state therefore has an obligation to ensure that its actions will always be for the benefit of society, and that it will steer away from activities that could harm society. ${ }^{[9]}$

At the forefront of the Life Esidimeni tragedy were Dr Tiego Ephraim Selebano (head of the GDoH) and Dr Makgabo Manamela (director, Mental Health), two qualified health professionals, who together with Qedani Mahlangu, the former MEC (Member of the Executive Council) for Health in Gauteng, were implicated as the three major players responsible for the tragedy. ${ }^{[6]}$ Both Dr Selebano and Dr Manamela have publicly taken oaths that they will not harm patients and that their actions will always be ethical and in the best interests of patients. Moreover, Mahlangu, upon taking office as MEC, promised to uphold South Africa's Constitution and all other laws of the country ${ }^{[4]}$ Caring and compassion are core values in the practice of healthcare, especially for the mentally ill, who require additional sensitively considered care. Did Mahlangu and others forget this, or did they choose not to remember? ${ }^{[10]}$

Autonomy is described as a rudimentary ethical principle in healthcare ${ }^{[8]}$ It is the right of individuals to make choices around their own health issues. In addition, individuals have the right to be involved in the decision-making process pertaining to their healthcare. The concept of informed consent is closely linked to autonomy, as informed consent is the voluntary un-coerced decision made by a competent autonomous individual to accept or reject some proposed course of action. ${ }^{[8]}$ Patients have the right to be informed about their treatment and care and to give consent before any treatment regimen can begin. However, autonomy and persons with mental illness pose a moral challenge. Individuals with mental illness do not always have the cognitive ability to make sound judgments pertaining to their health, and are therefore sometimes impaired with regard to the consent process. ${ }^{[11]}$ Nevertheless, even if an individual is found to lack the cognitive capacity to make an informed choice, she or he should still be included as far as possible in the decisionmaking process. ${ }^{[11]}$

The notion of autonomy and informed consent is also promulgated by law. Section 12(2) of the Constitution, ${ }^{[4]}$ the Mental Health Care Act (MHCA) (chapter 3) ${ }^{[12]}$ and the National Health Act (NHA) (chapter 2) ${ }^{[13]}$ all specifically deal with autonomy and informed consent. In certain circumstances, e.g. mental incapacity, individuals may not have the ability to consent. The NHA does, however, make provision for certain individuals to consent on behalf of these patients: ${ }^{[13]}$ ' $A$ person authorised by the court (e.g. a curator); or in order of priority, the patient's spouse, partner, parent, grandparent, major child or brother or sister.'

The MHCA ${ }^{[12]}$ stipulates that consent to care and treatment can only be provided by the patient, except where care and treatment is authorised by a court of law or where the mental state of the patient could cause serious harm or death to others or cause serious damage to property. The Act makes it clear that patients should be encouraged to give consent. Family members had the legal authority to provide consent on behalf of the patients at Life Esidimeni, and this included giving consent for patients to be transferred - a decision they were not involved in. ${ }^{[6]}$

Beneficence requires that the patient's interests be put first - that is, balancing benefits (interests) against risks and costs. Non-maleficence stems from the maxim Primum non nocere, meaning 'Above all (or first) do no harm. ${ }^{\text {'[14] }}$ It is an obligation to avoid harm to the patient or avoid going against the patient's interests. The character of beneficence rests on three values: preventing the infliction of unnecessary pain preventing mortality, and preventing the incapacitation of others. ${ }^{[11]}$ In the case of non-maleficence, the three values are do not kill, do not cause unnecessary pain, and do not incapacitate others. ${ }^{[1]}$ Clearly these six values were infringed in the Life Esidimeni tragedy. The patients and their families suffered unnecessary and preventable pain. There was utter disrespect for their dignity and welfare.

\section{B A Ferlito, A Dhai}

Steve Biko Centre for Bioethics, Faculty of Health Sciences, University of the Witwatersrand, Johannesburg, South Africa ames.dhai@wits.ac.za

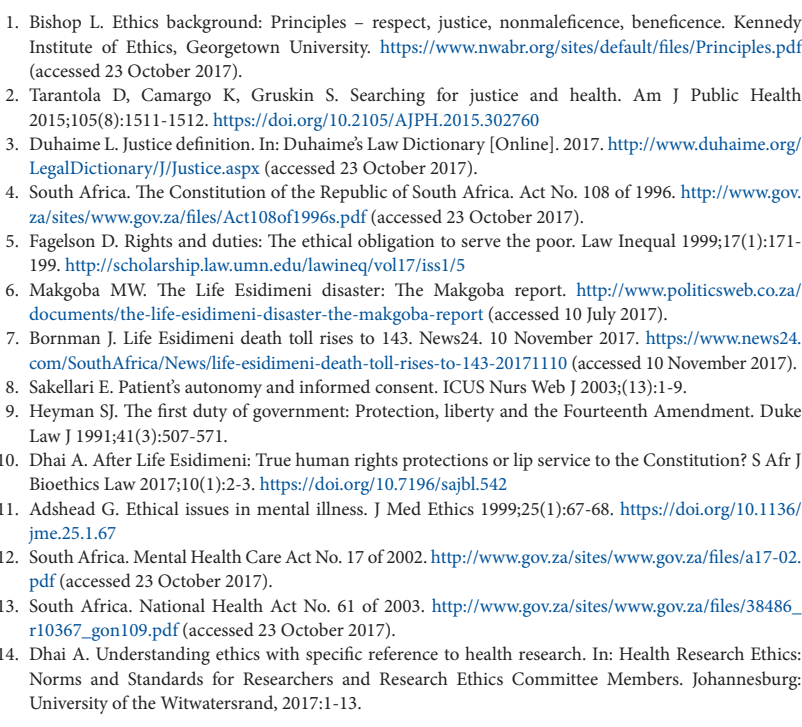

1. Bishop L. Ethics background: Principles - respect, justice, nonmaleficence, beneficence. Kennedy Institute of Ethics, Georgetown University. https://www.nwabr.org/sites/default/files/Principles.pd (accessed 23 October 2017).

. Tarantola D, Camargo K, Gruskin S. Searching for justice and health. Am J Public Health 2015;105(8):1511-1512. https://doi.org/10.2105/AJPH.2015.302760

Duhaime L. Justice definition. In: Duhaimes Law Dictionary [Online]. 2017. http://www.duhaime.org LegalDictionary///Justice aspx (accessed 23 October 2017).

4. South Africa. The Constitution of the Republic of South Africa. Act No. 108 of 1996. http.//www gov. za/sites/www.gov.za/files/Act108 of 1996s.pdf (accessed 23 October 2017).

za/sis Fa Dow Felson D. Rights and duties. The ethical obligation to serve the poor. Law in

6akgoba MW. The Life Esidimeni disaster: The Makgoba report. http://www.politicsweb.co.za/ documents/the-life-esidimeni-disaster-the-makgoba-report (accessed 10 July 2017).

Bornman J. Life Esidimeni death toll rises to 143. News24. 10 November 2017. https://www.news24. com/SouthAfrica/News/life-esidimeni-death-toll-rises-to-143-20171110 (accessed 10 November 2017) 8. Sakellari E. Patient's autonomy and informed consent. ICUS Nurs Web J 2003;(13):1-9.

9. Heyman SJ. The first duty of government: Protection, liberty and the Fourteenth Amendment. Duke Law J 1991;41(3):507-571.

0. Dhai A. After Life Esidimeni: True human rights protections or lip service to the Constitution? S Afr Bioethics Law 2017;10(1):2-3. https://doi.org/10.7196/sajbl.542

1. Adshead G. Ethical issues in mental illness. J Med Ethics 1999;25(1):67-68. https://doi.org/10.1136 jme.25.1.67

2. South Africa. Mental Health Care Act No. 17 of 2002 http.//www govza/sites/www gov za/files/a17-02. pdf (accessed 23 October 2017)

13. South Africe. Natiol Heath Act No. 61 of 2003 . http //www govza/sites/wwwgovza/fies/38486 r10367 gon 109 .

(1) 4. Dhai A. Undesstanding ellics wh specific reference to health resenrch. In. Healh Research Ethic Norms and Standards for Researchers and Research Ethics Committee Members. Johannesburg University of the Witwatersrand, 2017:1-13. 